\title{
Delayed Recognition of Levetiracetam-induced Pancytopenia
}

\author{
Mohammad Ammad Ud Din ${ }^{1}$, Syed Ather Hussain ${ }^{1}$, Amy Bodrog ${ }^{2}$ \\ ${ }^{1}$ Internal Medicine, Rochester General Hospital, Rochester, New York, USA \\ ${ }^{2}$ Hematology/Oncology, Rochester General Hospital, Rochester, New York, USA
}

Received: 06/03/2021

Accepted: $11 / 03 / 2021$

Published: 30/03/2021

How to cite this article: Ammad Ud Din M, Ather Hussain S, Bodrog A. Delayed recognition of levetiracetem-induced pancytopenia. EJCRIM 2021;8: doi:10.12890/2021_002449.

Conflicts of Interests: The Authors declare that there are no competing interests.

This article is licensed under a Commons Attribution Non-Commercial 4.0 License

\section{ABSTRACT}

Blood dyscrasias associated with levetiracetam use can be difficult to identify, especially when other potential differential diagnoses are concurrently present. Here we present a 57-year-old man with metastatic adenocarcinoma of unknown primary origin on levetiracetam who initially presented with an in-stent thrombosis of the right external iliac vein and then developed worsening thrombocytopenia followed by pancytopenia. Levetiracetam was not identified as the culprit until other causes like platelet consumption, heparin-induced thrombocytopenia, idiopathic immune thrombocytopenic purpura, and bone marrow involvement by metastatic disease were ruled out.

\section{LEARNING POINTS}

- Levetiracetam can cause both acute and delayed-onset pancytopenia through bone marrow suppression.

- The phenomenon is normally reversible and blood counts improve with drug cessation.

- Clinicians should consider checking a complete blood profile within a month of drug initiation, particularly in high-risk patients.

\section{KEYWORDS}

Drug-induced-pancytopenia, thrombocytopenia, levetiracetam, hematology, anti-epileptics

\section{CASE DESCRIPTION}

A 57-year-old man with a history of adenocarcinoma of unknown primary origin with metastases to the bone, liver, lungs and brain presented with an acute right lower extremity deep vein in-stent thrombosis. Previously, approximately a year ago, he was found to have high-grade stenosis of the distal right external iliac vein from a large tumour in the right hemipelvis which was stented, and he was started on apixaban. His systemic disease responded well to 11 cycles of carboplatin/paclitaxel and pelvic radiation, but unfortunately, 1 month before the presentation, he developed a right frontal lobe brain metastasis requiring whole brain radiation. He was started on levetiracetam $500 \mathrm{mg}$ and dexamethasone $4 \mathrm{mg}$ twice daily for seizure prophylaxis. His cell counts were within the normal range at the time of initiation of the medication, but on presentation, his platelet count had fallen to 35,000/ul. His white blood cell count (WBC) and haemoglobin were $11,000 / \mu \mathrm{l}$ and $15.1 \mathrm{~g} / \mathrm{dl}$, respectively (Table 1). His thrombocytopenia was initially attributed to platelet consumption secondary to the thrombus formation. The peripheral blood smear showed no giant platelets, schistocytes, immature cell lines or platelet clumping. His last cycle of chemotherapy was 2 months prior to presentation. Heparin-induced thrombocytopenia (HIT) was unlikely as his platelet count was low before the initiation of heparin this admission. Haptoglobin, vitamin B12, folate, lactate dehydrogenase, liver function tests and total bilirubin were all normal. 


\begin{tabular}{|l|l|l|l|}
\hline Timing & Haemoglobin $(\mathrm{g} / \mathrm{dll})$ & White blood cells $\left(10^{3} / \mu \mathrm{l}\right)$ & Platelet count $\left(10^{3} / \mathrm{\mu l}\right)$ \\
\hline On initiation of levetiracetam & 12.9 & 8.0 & 138 \\
\hline On admission & 15.1 & 11.0 & 35 \\
\hline On 10th day of hospitalization & $8.4^{*}$ & 0.8 & $47^{*}$ \\
\hline On 17th day of hospitalization & $10.8^{*}$ & 1.6 & $28^{*}$ \\
\hline
\end{tabular}

Table 1. A summary of the patient's complete blood picture during the hospital stay (levetiracetam was stopped on the 9th day).

${ }^{*}$ The patient was receiving transfusions to keep the platelet count above 50,000 $\mu / \mathrm{l}$ and haemoglobin above $8 \mathrm{~g} / \mathrm{dl}$.

Given the thrombocytopenia, he was started on reduced-dose intravenous heparin after mechanical thrombectomy, but his platelet counts continued to drop below the threshold of 50,000/ $\mathrm{\mu l}$ despite repeated platelet transfusions. On the 4 th day of hospitalization, he developed a left cerebellar bleed due to the progression of brain metastases, requiring heparin reversal with protamine. He underwent a suboccipital craniotomy and levetiracetam was increased to $750 \mathrm{mg}$ twice daily thereafter for seizure prophylaxis following the initial loading dose. All his cell lines continued to drop, and on the 10th day of hospitalization his white blood cell count reached a nadir of $800 / \mu l$ with an absolute

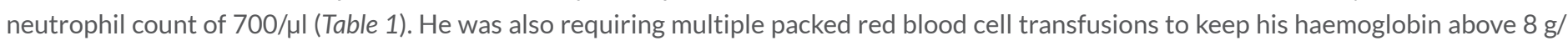
dl. No abnormalities were seen on review of multiple blood smears. Considering metastatic involvement of the marrow, a bone marrow biopsy of the right iliac bone was done which instead revealed a hypocellular marrow (Fig. 1). His pancytopenia was considered secondary to levetiracetam which was switched to topiramate $75 \mathrm{mg}$ twice daily on the 9th day of hospitalization. His WBC gradually improved to $1600 /$ $\mu$ l on the 17th day of hospitalization, after which he pursued hospice care as his functional status was severely compromised after the cranial surgery.

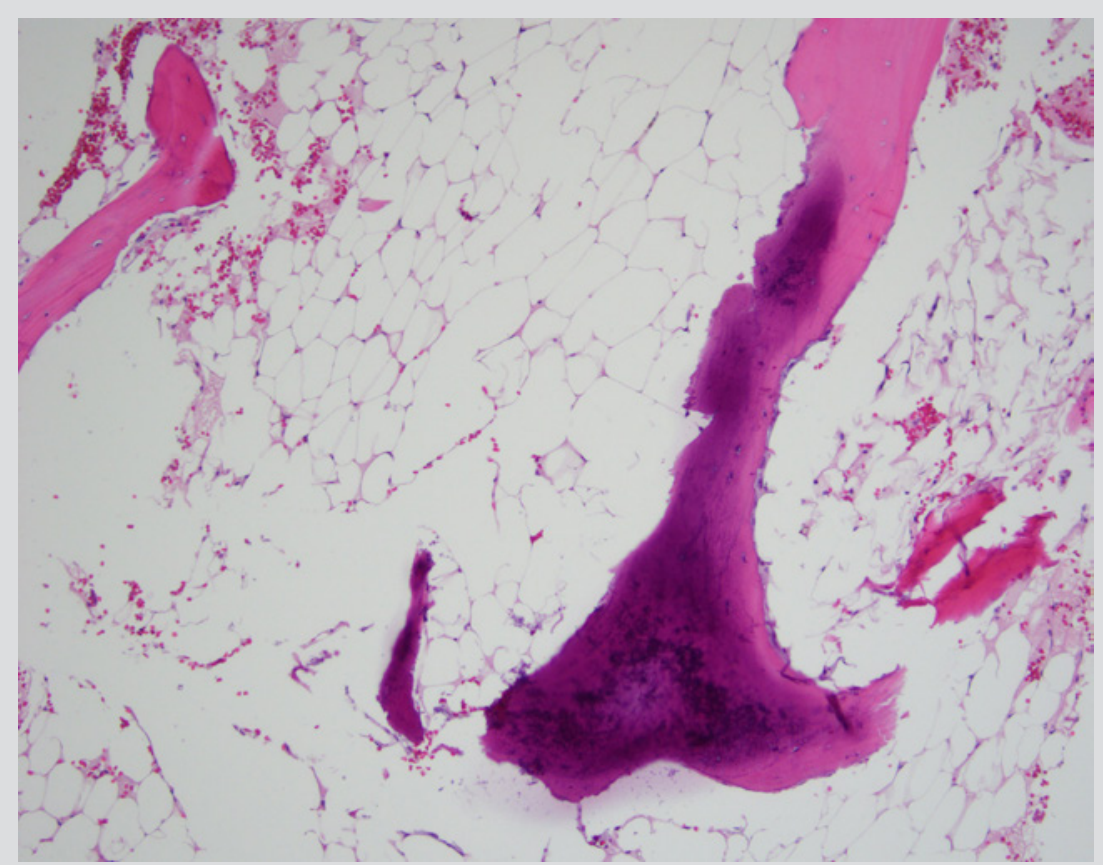

Figure 1. A hypocellular marrow can be seen on the core bone biopsy. No malignant or atypical cells can be visualized (haematoxylin and eosin stain: 10× magnification) 


\section{DISCUSSION}

Multiple case reports have shown levetiracetam (LEV) to cause both isolated thrombocytopenia and pancytopenia (Table 2) ${ }^{[1-13]}$. The phenomenon has been seen in both the adult and paediatric populations ${ }^{[1-4]}$. Usually, the fall in blood counts is drastic and a causal temporal relation with the drug is easy to establish ${ }^{[1,2,5,7]}$. Consequently, the culprit agent is swiftly identified, and the cessation of use leads to a rapid recovery in counts. In some instances, however, the drop in cell counts can be gradual, and since it is not a common practice to check blood work in patients on LEV, patients can remain on the drug until the blood dyscrasias are incidentally found on laboratory testing for other reasons ${ }^{[8,10]}$. It is in such cases, like that of our patient where the thrombocytopenia was noticed a month after starting LEV, that the diagnosis can be challenging. Our patient continued to remain on LEV until the 9th day of hospitalization as his thrombocytopenia was thought to be secondary to platelet consumption following the large venous thrombosis. Despite being on heparin, when his counts continued to fall, other differentials were considered. As he was already on a high dose of steroids, idiopathic thrombocytopenic purpura was unlikely, and there were no abnormalities on review of multiple blood smears. The calculated 4T score resulted in a low probability for HIT. It was only when no metastatic disease was seen on the marrow biopsy that LEV-induced pancytopenia was established as a diagnosis of exclusion. Although similar marrow findings were reported by Oghlakian et al. ${ }^{[8]}$, our patient previously had radiation therapy for his pelvic mass, so whether the histological changes can solely be attributed to LEV is debatable as Mohamed et al. noted a normal cellular marrow in their case of a 6-year-old male ${ }^{[4]}$.

In patients with prolonged exposure, the stability of the haematological profile can be delayed for about a month ${ }^{[8,9]}$. Our patient remained transfusion-dependent after drug cessation and then opted for hospice care on day 17. It is unclear what co-morbidities put patients at a higher risk of LEV-related blood dyscrasias, but a large study of 758 patients on LEV identified immunodeficiency as a possible contributor ${ }^{[0]}$, so perhaps a history of metastatic cancer made our patient more vulnerable to this idiosyncratic reaction.

\section{CONCLUSION}

LEV-induced bone marrow suppression is a rare but important differential to consider in patients with new-onset isolated thrombocytopenia or pancytopenia. It may become difficult to diagnose the condition especially when other differential diagnoses also need to be equally considered. As most cases occur within the first month of initiation of the medication, it may be prudent to check a complete blood count during this time frame and follow patients closely if a drop in cell counts is seen.

\section{REFERENCES}

1. Bangash O, Simonin A, Tsimiklis C, Ramakonar H, Honeybul S. Prophylactic levetiracetam-induced pancytopenia with traumatic extra-dural hematoma: case report. J Clin Neurosci 2020;80:264-266. doi: 10.1016/j.jocn.2020.08.004

2. Alzahrani T,Kay D,Alqahtani SA, MakkeY,Lesky L, Koubeissi MZ. Levetiracetam-induced pancytopenia. EpilepsyBehav Case Rep 2015;4:45-47.doi: 10.1016/j.ebcr.2015.06.001

3. Gohil JR, Agarwal TS. Levetiracetam adverse drug reaction: pancytopenia. J Pediatr Neurosci 2018;13(1):116-117.doi: 10.4103/JPN.JPN_139_17

4. Mohamed B Peer, Prabhakar P. Thrombocytopenia as an adverse effect of levetiracetam therapy in a child [published correction appears in Neuropediatrics 2009;40(5):244. Mohamed, B P [corrected to Peer Mohamed, B]. Neuropediatrics 2009;40(5):243-244. doi: 10.1055/s-0030-1247524

5. García Carretero R, Romero Brugera M, Olid-Velilla M, Salamanca-Ramirez I. Pancytopenia associated with levetiracetam in an epileptic woman. BMJ Case Rep 2016;2016:bcr2016217407. doi: 10.1136/bcr-2016-217407

6. Aydoğan Harun, Yalçn Şaban, Karahan Mahmut Alp, Büyükfrat Evren. Pancytopenia associated with levetiracetam treatment in Lafora's disease. Blood Coagul Fibrinolysis 2012;23(2):175. doi: 10.1097/MBC.0b013e32834bdb5f

7. Elouni B, Ben Salem C, Biour M. Levetiracetam-induced pancytopenia. Ann Pharmacother 2009;43(5):985. doi: 10.1345/aph.1L727

8. Oghlakian R, Nock C, Koubeissi M. A case of levetiracetam-induced thrombocytopenia. Epileptic Disord 2010;12(4):335-337. doi:10.1684/epd.2010.0343

9. Sahaya K, Goyal MK, Sarwal A, Singh NN. Levetiracetam-induced thrombocytopenia among inpatients: a retrospective study. Epilepsia 2010;51(12):2492-2495. doi: 10.1111/j.1528-1167.2010.02788.x

10. Kimland E, Höjeberg B, von Euler M. Levetiracetam-induced thrombocytopenia. Epilepsia 2004:45(7):877-878. doi: 10.1111/j.0013-9580.2004.64903.x

11. Meschede A, Runge U, Sabolek M. Thrombocytopenia during levetiracetam therapy. Epilepsy Res 2008;80(1):91-92. doi: 10.1016/j.eplepsyres.2008.03.002

12. Kim Jonguk, Jung-Won Shin. Levetiracetam-induced thrombocytopenia in a patient with status epilepticus. Epileptic Disord 2017;19(1):104-108. doi: 10.1684/epd.2017.0889

13. Gallerani M, Mari E, Boari B, Carletti R, Marra A, Cavallo M. Pancytopenia associated with levetiracetam treatment. Clin Drug Investig 2009;29(11):747-751. doi: $10.2165 / 11319450-000000000-00000$ 


\begin{tabular}{|c|c|c|c|c|c|c|}
\hline \multicolumn{7}{|c|}{ Cases of pancytopenia } \\
\hline $\begin{array}{l}\text { Author(s) } \\
\text { (year) }\end{array}$ & $\begin{array}{l}\text { Patient } \\
\text { age/gender }\end{array}$ & $\begin{array}{l}\text { Indication for } \\
\text { levetiracetam use }\end{array}$ & $\begin{array}{l}\text { Time to first } \\
\text { noticeable drop } \\
\text { in cell counts }\end{array}$ & $\begin{array}{l}\text { Total length of } \\
\text { exposure }\end{array}$ & Count recovery? & $\begin{array}{l}\text { Long-term } \\
\text { anti-seizure drug } \\
\text { regimen }\end{array}$ \\
\hline $\begin{array}{l}\text { Bangash et al. } \\
(2020)[1]\end{array}$ & $32 \mathrm{y} / \mathrm{M}$ & $\begin{array}{l}\text { Seizure prophylaxis } \\
\text { after extradural } \\
\text { haematoma evacuation }\end{array}$ & 3 days & 4 days & $\begin{array}{l}\text { Yes (all cell lines } \\
\text { within a week) }\end{array}$ & $\begin{array}{l}\text { Remained off any anti-seizure } \\
\text { medication }\end{array}$ \\
\hline $\begin{array}{l}\text { Gohil et al. } \\
\text { (2018) [3] }\end{array}$ & $4 \mathrm{mth} / \mathrm{M}$ & $\begin{array}{l}\text { Primary seizure } \\
\text { disorder }\end{array}$ & 8 days & 8 days & No & $\begin{array}{l}\text { Patient died due to septic } \\
\text { shock from pneumonia }\end{array}$ \\
\hline $\begin{array}{l}\text { García } \\
\text { Carretero et al. } \\
\text { (2016) [5] }\end{array}$ & $77 y / F$ & $\begin{array}{l}\text { Seizure after ischaemic } \\
\text { stroke }\end{array}$ & 2 days & 2 days & $\begin{array}{l}\text { Yes (all cell lines } \\
\text { within } 2 \text { weeks) }\end{array}$ & Not mentioned \\
\hline $\begin{array}{l}\text { Alzahrani et al. } \\
\text { (2015) [2] }\end{array}$ & $79 y / F$ & $\begin{array}{l}\text { Seizure prophylaxis for } \\
\text { brain mass }\end{array}$ & 5 days & 10 days & $\begin{array}{l}\text { Yes (all cell lines } \\
\text { within a week) }\end{array}$ & Switched to lacosamide \\
\hline $\begin{array}{l}\text { Aydoğan et al. } \\
\text { (2012) [6] }\end{array}$ & $16 \mathrm{y} / \mathrm{F}$ & Lafora's disease & 4 days & 4 days & $\begin{array}{l}\text { Yes (all cell lines } \\
\text { within a week) }\end{array}$ & Not mentioned \\
\hline $\begin{array}{l}\text { Elouni et al. } \\
\text { (2009) [7] }\end{array}$ & $76 \mathrm{y} / \mathrm{F}$ & $\begin{array}{l}\text { Seizure after ischaemic } \\
\text { stroke }\end{array}$ & 2 days & 4 days & $\begin{array}{l}\text { Yes (all cell lines } \\
\text { within a week) }\end{array}$ & $\begin{array}{l}\text { Rechallenged with } \\
\text { levetiracetam } 1 \text { week later, } \\
\text { but switched to clobazam } \\
\text { because of pancytopenia }\end{array}$ \\
\hline $\begin{array}{l}\text { Gallerani et al. } \\
\text { (2009) [13] }\end{array}$ & $65 \mathrm{y} / \mathrm{F}$ & $\begin{array}{l}\text { Seizure prophylaxis } \\
\text { after meningioma } \\
\text { removal }\end{array}$ & 9 days & 18 days & $\begin{array}{l}\text { Yes (all cell lines } \\
\text { within a week) }\end{array}$ & $\begin{array}{l}\text { Remained off any anti-seizure } \\
\text { medication }\end{array}$ \\
\hline \multicolumn{7}{|c|}{ Cases of isolated thrombocytopenia } \\
\hline $\begin{array}{l}\text { Kimetal. } \\
\text { (2017) [12] }\end{array}$ & $77 y / F$ & $\begin{array}{l}\text { Seizure following } \\
\text { cardiopulmonary } \\
\text { resuscitation }\end{array}$ & 13 days & 16 days & $\begin{array}{l}\text { Yes (platelet count } \\
\text { within a week) }\end{array}$ & Remained on topiramate \\
\hline $\begin{array}{l}\text { Oghlakian et al. } \\
\text { (2010) [8] }\end{array}$ & $50 y / F$ & $\begin{array}{l}\text { Seizure disorder } \\
\text { secondary to } \\
\text { glioblastoma } \\
\text { multiforme }\end{array}$ & 1 month & $>6$ months & $\begin{array}{l}\text { Yes (platelet count } \\
\text { within } 1 \text { month) }\end{array}$ & Not mentioned \\
\hline $\begin{array}{l}\text { Sahaya et al. } \\
\text { (2010) [9] }\end{array}$ & $35 \mathrm{y} / \mathrm{M}$ & $\begin{array}{l}\text { Primary seizure } \\
\text { disorder }\end{array}$ & 133 days & 133 days & $\begin{array}{l}\text { Yes (platelet count } \\
\text { within } 3 \text { weeks) }\end{array}$ & Remained on clonazepam \\
\hline $\begin{array}{l}\text { Mohamed et al. } \\
\text { (2009) [4] }\end{array}$ & $6 y / M$ & $\begin{array}{l}\text { Seizures secondary to } \\
\text { cerebral venous sinus } \\
\text { thrombosis }\end{array}$ & 5 weeks & Not mentioned & $\begin{array}{l}\text { Yes (platelet count } \\
\text { after } 4 \text { weeks) }\end{array}$ & Not mentioned \\
\hline $\begin{array}{l}\text { Meschede et al. } \\
\text { (2008) [11] }\end{array}$ & $64 \mathrm{y} / \mathrm{F}$ & $\begin{array}{l}\text { Primary seizure } \\
\text { disorder }\end{array}$ & 3 days & 12 days & $\begin{array}{l}\text { Yes (platelet count } \\
\text { within a week) }\end{array}$ & Not mentioned \\
\hline $\begin{array}{l}\text { Kimland et al. } \\
\text { (2004) [10] }\end{array}$ & $49 y / M$ & $\begin{array}{l}\text { Seizure disorder } \\
\text { secondary to } \\
\text { oligoastrocytoma }\end{array}$ & 20 days & Not mentioned & $\begin{array}{l}\text { Yes (platelet count } \\
\text { after } 5 \text { weeks) }\end{array}$ & Not mentioned \\
\hline
\end{tabular}

Table 2. Summary of previously reported cases of levetiracetam-induced pancytopenia and thrombocytopenia.

F, female; M, male; $m$ th, months; $y$, years. 